\title{
INCREASED MORTALITY AMONG CALVES IN DANISH CATTLE HERDS DURING BOVINE VIRUS DIARRHOEA INFECTION
}

\author{
Ersbøll A.K. ${ }^{1}$, Rugbjerg H. ${ }^{1,2}$, Stryhn $H^{2}$ \\ ${ }^{1}$ Royal Veterinary and Agricultural University, Grønnegårdsvej 8, DK-1870 Frederiksberg C, Denmark \\ ${ }^{2}$ Danish Veterinary Laboratory, Bülowsvej 27, DK-1790 København V, Denmark
}

In a recent Danish study concerning calf mortality and health ${ }^{1}$ an overall calf mortality of $7.2 \%$ was found. The mortality was higher among Jersey than among Danish Holsteins. The mortality was highest in the age interval 1-14 days compared to 15-180 days, higher in the winter than in the summer and higher on larger farms compared to smaller farms.

In 1994, Bovine Virus Diarrhoea (BVD) was endemic in Denmark with Persistently Infected (PI)animals present in around $40 \%$ of the herds ${ }^{2,3}$. In 1994, a voluntary control and eradication programme was initiated by the farmers' organisations ${ }^{2}$. The programme was supported by national legislation from April $1996^{4}$. The aim of this study was to compare the calf mortality in herds affected with BVD to the calf mortality in cattle herds free from BVD. Furthermore, the associations between various risk factors and increased mortality in the BVD infected herds compared to non-BVD herds were estimated.

A database covering the period January 1995 to November 1999 was created, based on an extraction from the Danish Cattle database. Definition of PI-animals and herds has been described by Alban et al. ${ }^{5}$. In the present study a BVD herd was defined as a herd with occurrence of a PI-animal after study onset (i.e. after 1.1.1995). The study population included only herds participating in the Milk Recording Scheme, animals which were not moved during the study period and the following breeds: Only Red Danish Dairy breed, Danish Holsteins, Jersey, Red and White Danish Dairy breed and crosses of milk breed. Calves were defined as animals with an age below 365 days. Logistic regression analysis was used to estimate and evaluate the effect of the risk factors: Herd size, year and BVD-status. The analysis was performed on herd level, analysing the proportion of calves died to the total number of calves in each herd.

A total of 211.386 calves from BVD herds and 2.174.440 calves from BVD free herds were included in the study. The calf mortality was $14.6 \%$ and $7.3 \%$ in BVD and BVD free herds, respectively. Being a BVD herd increased significantly the risk of increased calf mortality $(p<0.001)$. Year was significantly associated with calf mortality. Increasing herd size significantly increased the calf mortality.

\section{References}

1. Nielsen, L.A.H., 2001. Hvilke kalve får en god start? (Danish). Annual meeting of the Danish Cattle Breeding Associations, State Department for Cattle. Herning, 42-43.

2. Bitsch, V. and Rønsholt, L., 1995. Control of bovine viral diarrhea virus infection without vaccines. Vet. Clin. North Am. Food Anim. Pract. 11: 627-640.

3. Houe, H., 1994. Bovine virus diarrhea virus: detection of Danish dairy herds with persistently infected animals by means of a screening test of ten young stock. Prev. Vet. Med. 19: 241-248.

4. Anonymous,1996. Bekendtgørelse nr. 154 af 21. Marts 1996 om BVD hos kvæg. (Regulation No. 154 of March 21st 1996 regarding BVD in Cattle). Veterinær- og Fødevaredirektoratet, Søborg, Denmark. 2pp.

5. Alban, L., Stryhn, H., Kjeldsen, A.M., Ersbøll, A.K., Skjøth, F. Christensen, J., Bitsch, V., Chriél, M. and Strøger, U., 2001. Estimating transfer of Bovine virus diarrhoea virus in Danish cattle by use of register data. Submitted to Prev. Vet. Med. 